\title{
IgE-Api m 4 Is Useful for Identifying a Particular Phenotype of Bee Venom Allergy
}

\author{
Ruiz $\mathrm{B}^{1,2}$, Serrano $\mathrm{P}^{1,2}$, Moreno $\mathrm{C}^{1,2}$
}

\author{
'Maimonides Biomedical Research Institute of Cordoba (IMIBIC) \\ ${ }^{2}$ Department of Allergology, Reina Sofia University Hospital, Córdoba, Spain
}

J Investig Allergol Clin Immunol 2016; Vol. 26(6): 355-361

doi: $10.18176 /$ jiaci.0053

\begin{abstract}
Background and Objective: Different clinical behaviors have been identified in patients allergic to bee venom. Compound-resolved diagnosis could be an appropriate tool for investigating these differences. The aims of this study were to analyze whether specific IgE to Api $\mathrm{m} 4$ (slgE-Api m 4) can identify a particular kind of bee venom allergy and to describe response to bee venom immunotherapy (bVIT). Methods: Prospective study of 31 patients allergic to bee venom who were assigned to phenotype group A (slgE-Api m $4<0.98 \mathrm{kU} / \mathrm{L}$ ), treated with native aqueous (NA) extract, or phenotype group B (slgE-Api m $4 \geq 0.98 \mathrm{kU} / \mathrm{L}$ ), treated with purified aqueous (PA) extract. Sex, age, cardiovascular risk, severity of preceding sting reaction, exposure to beekeeping, and immunological data (intradermal test, slgE/ slgG4-Apis-nApi m 1, and slgE-rApi m 2-Api m 4 were analyzed. Systemic reactions (SRs) during bVIT build-up were analyzed. Immunological and sting challenge outcomes were evaluated in each group after 1 and 2 years of bVIT.

Results: Phenotype B patients had more severe reactions $(P=.049)$ and higher skin sensitivity $(P=.011)$, baseline slgE-Apis $(P=.0004)$, slgE-nApi $m 1(P=.0004)$, and slgG4-Apis ( $P=.027)$ than phenotype A patients. Furthermore, $41 \%$ of patients in group $B$ experienced SRs during the build-up phase with NA; the sting challenge success rate in this group was $82 \%$. There were no significant reductions in serial intradermal test results, but an intense reduction in slgE-nApi m $1(P=.013)$ and slgE-Api m $4(P=.004)$ was observed after the first year of bVIT.

Conclusion: Use of IgE-Api m 4 as the only discrimination criterion demonstrated differences in bee venom allergy. Further investigation with larger populations is necessary.
\end{abstract}

Key words: Bee venom allergens. Bee venom immunotherapy. Component-resolved diagnosis. Sting challenge. Systemic reaction.

\section{Resumen}

Antecedentes y Objetivos: Los pacientes alérgicos a veneno de abeja muestran distintos comportamientos clínicos. El diagnóstico por componentes podría ayudar a entenderlos. El objetivo de este estudio fue estudiar la capacidad de la IgE-Api m4 para identificar diferentes patrones de alergia al veneno de abeja, incluyendo la respuesta a la inmunoterapia al veneno de abeja (ITVa).

Métodos: Estudio prospectivo de 31 pacientes alérgicos al veneno de abeja, distribuidos en dos grupos fenotípicos (A y B) en función de sus niveles de IgE-Api m4 (punto de corte 0,98 kU/L) y tratados con extracto acuoso nativo (AN)-fenotipo A, o extracto acuoso purificado (AP)-fenotipo B. Se analizaron sexo, edad, riesgo cardiovascular, gravedad de la picadura, exposición y datos inmunológicos (intradermorreación, lgE e lgG4-Apis-nApi m1 e lgE-rApi m2-Api m4). Se analizó la seguridad en la fase de inicio de la ITVa, y la eficacia y cambios inmunológicos después de 1 y 2 años de ITVa.

Resultados: El fenotipo-B mostró reacciones más graves con las picaduras $(p=0,049)$, una mayor sensibilidad cutánea ( $p=0,011)$ y valores más elevados de IgE-Apis ( $p=0,0004)$, IgE-nApim1 ( $p=0,0004)$, e lgG4-Apis $(p=0,027)$ que el fenotipo-A. Por otra parte, el $41 \%$ de los pacientes del fenotipo-B sufrió reacciones sistémicas durante el inicio con AN, con una tasa de protección del $82 \%$. La respuesta cutánea no mejoró significativamente, y se comprobó la reducción intensa de IgE-nApi m1 $(p=0,013)$ e lgE-Api m4 $(p=0,004)$ desde el primer año de ITVa.

Conclusión: El uso de la IgE-Api m4 como único criterio discriminativo ha podido confirmar que hay diferentes maneras de ser alérgico al Va. Se necesitan estudios en poblaciones más amplias.

Palabras clave: Alérgenos del veneno de abeja. Inmunoterapia con veneno de abeja. Diagnóstico por componentes. Repicadura. Reacción sistémica. 


\section{Introduction}

Bee venom immunotherapy (bVIT) is known to be associated with a greater risk of systemic reactions (SRs) and less protection against bee stings than vespid VIT [1].

Twelve allergens have been identified in honeybee venom (HBV) to date [3]. The best known are phospholipase A2 (Api m 1), hyaluronidase (Api m 2), and melittin (Api m 4). Api $\mathrm{m} 1$ is the most common allergen detected by specific IgE (sIgE) determination, regardless of the method used [4-6]. Api $\mathrm{m} 2$ is a cross-reactivity marker [7], while Api $\mathrm{m} 4$ is a 2.84-kDa peptide that is found in abundance in venom [8] but has been associated with low allergenicity [4]. The combined use of these 3 components, which make up the bulk of the dry weight of venom, was found to increase diagnostic performance by $15 \%$ compared with the use of rApi m 1 alone [9]. A later study using 6 different HBV components showed the complexity of sensitization profiles in patients with HBV allergy [4].

A recent study reported a high prevalence of sensitization to Api m 4 among HBV-allergic patients who experienced SRs during induction of bVIT, suggesting an association between SRs and sensitization to Api m 4 [10]. Furthermore, allergenic extracts currently available for bVIT are standardized on the basis of their enzymatic activity and total protein content, with no consideration of individual components. The above aspects raise the question of whether $\mathrm{HBV}$-allergic patients may have individual sensitization profiles that require a more specific diagnosis based on the determination of individual allergenic components rather than standardized diagnosis based on $\operatorname{sgE}$ to full extracts (intradermal testing [ID] and serum sIgE). Such an approach could help to tailor treatments to specific sensitization profiles.

The aim of this study was to analyze whether $\operatorname{sgE}$ to Api $m 4$ (SIgE-Api m 4) can identify a particular kind of HBV allergy in terms of clinical and sensitization profiles as well as predict response to bVIT.

\section{Methods}

\section{Study Design}

We conducted a longitudinal prospective study of patients with bee-sting anaphylaxis diagnosed by conventional and molecular tools and under treatment with bVIT. The study protocol was approved by the Clinical Research Ethics Committee of Reina Sofia University Hospital in Córdoba, Spain, and all participants provided their written informed consent.

\section{Demographics and Clinical Data}

We collected data on patients' sex, age, and exposure to beekeeping (yes/no) in addition to severity of stinginduced anaphylaxis (grades I-IV according to the Müller classification [11]) and presence of cardiovascular risk factors (coronary disease, hypertension, and $\beta$-blocker or angiotensinconverting enzyme inhibitor treatment).

\section{Conventional Diagnosis}

We performed serial ID with Apis mellifera (Apis) venom (ALK Abelló SA, Madrid, Spain) at increasing concentrations from 0.00001 to $0.1 \mu \mathrm{g} / \mathrm{mL}$. Degree of sensitization was established by the lowest concentration that produced a positive reaction (wheal with a mean diameter of $5 \mathrm{~mm}$ ).

Serum sIgE and sIgG4 to Apis were determined using ImmunoCAP (Thermo Fisher Scientific) according to the manufacturer's instructions. Quantitative results were expressed in $\mathrm{kU} / \mathrm{L}$ (sIgE) and $\mu \mathrm{g} / \mathrm{mL}$ (sIgG4).

Baseline serum tryptase levels were measured using ImmunoCAP Tryptase (Thermo Fisher Scientific).

\section{Molecular Diagnosis}

sIgE to molecular components of Apis venom-native Apim 1 (nApim 1) (Sigma-Aldrich, Madrid, Spain), recombinant Api $\mathrm{m} 2$ (rApi $\mathrm{m} 2$ expressed in purified cells infected with baculovirus) [7], and Api m 4 (a synthetic peptide) (Schafer-N, Denmark) - was determined using the ADVIA-Centaur system (Bayer Health Care Diagnostics Division) and expressed in $\mathrm{kU} / \mathrm{L}$ [12]. sIgG4-Api m 1 ( $\mu \mathrm{g} / \mathrm{mL})$ was determined using ImmunoCAP.

\section{Patients}

The patients were divided into 2 phenotype groups according to baseline levels of sIgE-Api $m$ 4: group A $(\operatorname{IgE}<0.98 \mathrm{kU} / \mathrm{L})$ and group $\mathrm{B}(\operatorname{IgE} \geq 0.98 \mathrm{kU} / \mathrm{L})$. In the absence of a validated reference, we chose a cutoff of $0.98 \mathrm{kU} / \mathrm{L}$ because this was the median value from a pilot sample of 25 biobank sera with detectable sIgE-Api m 4.

\section{Immunotherapy}

Immunotherapy was indicated according to international guidelines [13] and administered in all cases by the same members of the nursing staff of an immunotherapy unit under the direct supervision of an allergist. The nurses were all trained and experienced in recognizing and treating anaphylactic reactions.

The following HBV extracts were used for bVIT: native aqueous extract (NA) (Pharmalgen, ALK-Abelló SA, Madrid, Spain) and purified aqueous extract (PA) (Aquagen, ALKAbelló SA). According to the manufacturer's information, PA venom extract contains a very low quantity of the lowmolecular components present in the native extract, including, logically, Api m 4. In attempt to better match sensitization profiles to the allergen content of extracts, patients in phenotype group A were treated with PA while those in phenotype group B were treated with NA.

A build-up phase consisting of a previously described cluster protocol was used in all patients [14]. Maintenance therapy consisted of $200 \mu \mathrm{g}$ for patients with a high risk of exposure to bee stings and $100 \mu \mathrm{g}$ otherwise. Monthly injections were administered over a period of 2 years.

\section{Evaluation of bVIT Safety}

Occurrence (yes/no) and number of SRs during induction of immunotherapy were reported using the Müller classification [11]. All patients began bVIT without premedication to avoid confounding effects on the occurrence of SRs. Patients who experienced an SR following initiation of 
therapy were pretreated with dexchlorpheniramine $(5 \mathrm{mg})$ and methylprednisolone $(1 \mathrm{mg} / \mathrm{kg})$ at each subsequent appointment; the dose was not reduced.

\section{Evaluation of Sting Challenge}

An in-hospital sting challenge test with a live honeybee was offered to all patients who had reached the maintenance dose without experiencing SRs to evaluate treatment efficacy. The test was carried out after 1 and 2 years of immunotherapy, as described for vespids [15]. Responses were classified using the Müller system [11]. Patients with a negative result remained under observation for 2 hours after the challenge.

\section{Evaluation of Immunologic Markers}

ID responses were measured after 1 and 2 years of immunotherapy and grouped according to concentration (0.0001-0.1, 0.1, and $\geq 1 \mu \mathrm{g} / \mathrm{mL}$ ) for analysis. The lowest concentration that produced a wheal with a mean diameter of $5 \mathrm{~mm}$ was recorded as positive and a reduction in this concentration after 1 or 2 years was considered an ID improvement.

Serum sIgE and sIgG4 to Apis, sIgE-nApim 1-rApi m 2-Api $\mathrm{m} 4$, and sIgG4-pim 1 were also determined after 1 and 2 years of immunotherapy. All immunological data were analyzed separately by phenotype (groups A and B).

\section{Statistical Methods}

Quantitative values were described using means, SDs, medians, IQRs, and minimum and maximum values. The $t$ test and the Mann-Whitney $U$ test were applied for quantitative variables. The $\chi^{2}$ test, Fisher test, and Cochran-Armitage trend test were used to examine the independence between qualitative variables. To investigate associations between quantitative variables, Spearman's rank correlation coefficient was used. All analyses were performed with SAS statistical software version 9.3.

\section{Results}

\section{Patients and Sensitization Profile}

Thirty-one patients were included. Table 1 summarizes their demographic, clinical, and diagnostic characteristics and Figure 1 shows the population flow chart. According to the cutoff of $0.98 \mathrm{kU} / \mathrm{L}$ for sIgE-Api m 4, 19 patients were assigned to group A and 12 were assigned to group B. These groups represented 2 phenotypes characterized by differences in sting reaction severity, ID reaction intensity, baseline sIgE-Apis and sIgE-nApi $\mathrm{m} \mathrm{1}$, and baseline sIgG4-Apis (Table 1). Figure 2 shows the sensitization profiles for both phenotype groups.

\section{Clinical Changes in Group A bVIT Safety}

All 19 patients in group A were treated with PA. Thirteen were administered the $100-\mu \mathrm{g}$ maintenance dose and 6 were administered the 200- $\mu \mathrm{g}$ dose. Three patients experienced 2 Müller grade I SRs during the bVIT build-up phase; the
Table 1. Characteristics of Patients Allergic to Apis mellifera Venom by Phenotype

\begin{tabular}{|c|c|c|c|}
\hline & Phenotype $A^{a}$ & Phenotype $\mathrm{B}^{\mathrm{a}}$ & $\begin{array}{c}P \\
\text { value }\end{array}$ \\
\hline Patients, No. (\%) & $19(61.3)$ & $12(38.7)$ & \\
\hline Men, No. (\%) & $15(79)$ & $11(91.6)$ & .633 \\
\hline Age, mean (SD), y & $38(16.4)$ & $36.4(19)$ & .787 \\
\hline Beekeepers, No. (\%) & $10(52.6)$ & $8(66.6)$ & .484 \\
\hline 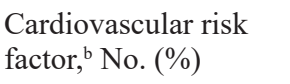 & $3(15.7)$ & $2(16.6)$ & 1.000 \\
\hline $\begin{array}{l}\text { Bee-sting reaction } \\
\text { grade, }{ }^{c} \text { No. }(\%) \\
\text { I } \\
\text { II } \\
\text { III } \\
\text { IV }\end{array}$ & $\begin{array}{c}3(15.7) \\
8(42) \\
7(36.8) \\
1(5.2)\end{array}$ & $\begin{array}{c}2(16.6) \\
0 \\
6(50) \\
4(33.3)\end{array}$ & .049 \\
\hline $\begin{array}{l}\text { sIgE to A mellifera, } \\
\text { median (IQR), kU/L }\end{array}$ & $4.3(11.5)$ & $35(52.6)$ & .0004 \\
\hline $\begin{array}{l}\text { Intradermal reaction } \\
\text { test, No. }(\%) \\
0.0001 \mu \mathrm{g} / \mathrm{mL} \\
0.001 \mu \mathrm{g} / \mathrm{mL} \\
0.01 \mu \mathrm{g} / \mathrm{mL} \\
0.1 \mu \mathrm{g} / \mathrm{mL} \\
\geq 1 \mu \mathrm{g} / \mathrm{mL}\end{array}$ & $\begin{array}{c}0 \\
6(31.5) \\
1(5.2) \\
7(37) \\
5(26.3)\end{array}$ & $\begin{array}{c}3(25) \\
5(41.6) \\
2(16.6) \\
1(8.3) \\
1(8.3)\end{array}$ & 0.011 \\
\hline $\begin{array}{l}\text { Baseline tryptase, } \\
\text { median (IQR), } \mu \mathrm{g} / \mathrm{L}\end{array}$ & $5.48(4.4)$ & $5.27(3)$ & .584 \\
\hline $\begin{array}{l}\text { sIgE nApi m 1, } \\
\text { median (IQR),kU/L }\end{array}$ & $5.12(12)$ & $55.2(77)$ & .0004 \\
\hline $\begin{array}{l}\text { sIgE rApi m 2, } \\
\text { median (IQR), kU/L }\end{array}$ & $1.52(7)$ & $5.5(127.5)$ & .221 \\
\hline $\begin{array}{l}\text { sIgE Api m 4, } \\
\text { median (IQR), kU/L }\end{array}$ & $0.3(0.5)$ & $2.7(8.2)$ & .0001 \\
\hline $\begin{array}{l}\text { sIgG4 A mellifera, } \\
\text { median (IQR), } \mu \mathrm{g} / \mathrm{mL}\end{array}$ & $698(1525)$ & $2235(6590)$ & .027 \\
\hline $\begin{array}{l}\text { sIgG4 Api m 1, } \\
\text { median (IQR), } \mu \mathrm{g} / \mathrm{mL}\end{array}$ & $1.2(1.9)$ & $3.3(3.5)$ & .096 \\
\hline
\end{tabular}

Abbreviations: slgE, specific lgE; slgG4, specific lgG4. aGroup A: slgE to Api m $4<0.98 \mathrm{kU} / \mathrm{L} ;$ Group B: slgE to Api m 4 $\geq 0.98 \mathrm{kU} / \mathrm{L}$.

${ }^{b}$ Coronary disease, hypertension, and treatment with $\beta$-blockers or angiotensin-converting enzyme inhibitors.

cField bee-sting reactions were graded with the Müller classification system [11].

second SR in each case occurred despite premedication. After completing the build-up phase, 1 patient withdrew due to reasons unrelated to the study.

\section{Sting Challenge}

The 18 patients in group A tolerated a sting challenge test 1 and 2 years after bVIT. 


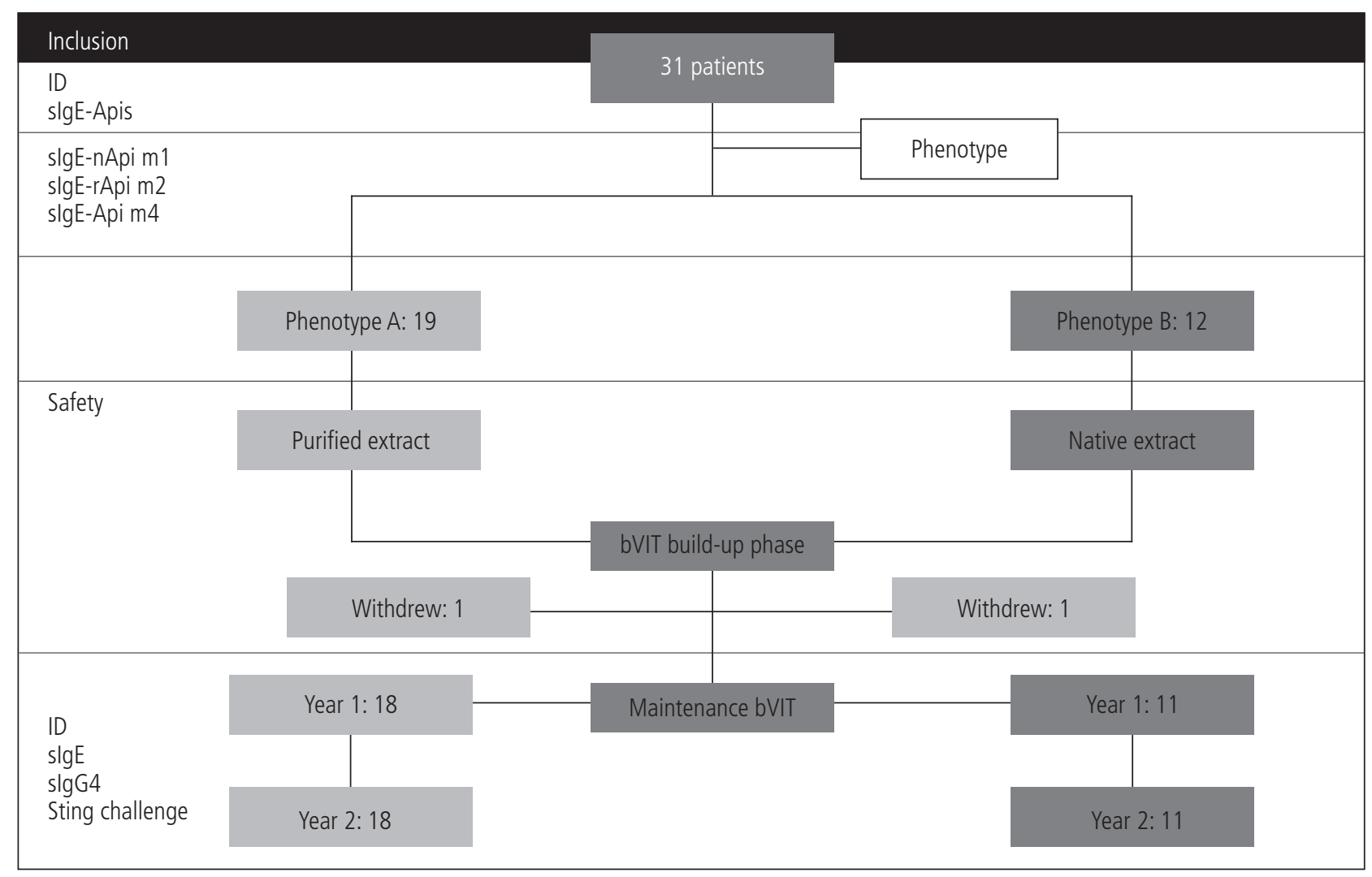

Figure 1. Flow chart showing diagnosis and bee venom immunotherapy therapy (bVIT) phases in patients with phenotype $\mathrm{A}$ (slgE to Api $\mathrm{m} 4<0.98 \mathrm{kU} / \mathrm{L}$ ) and phenotype B (slgE to Api $m 4 \geq 0.98$ kU/L). ID indicates intradermal test; slgE, specific lgE; slgG4, specific lgG4.

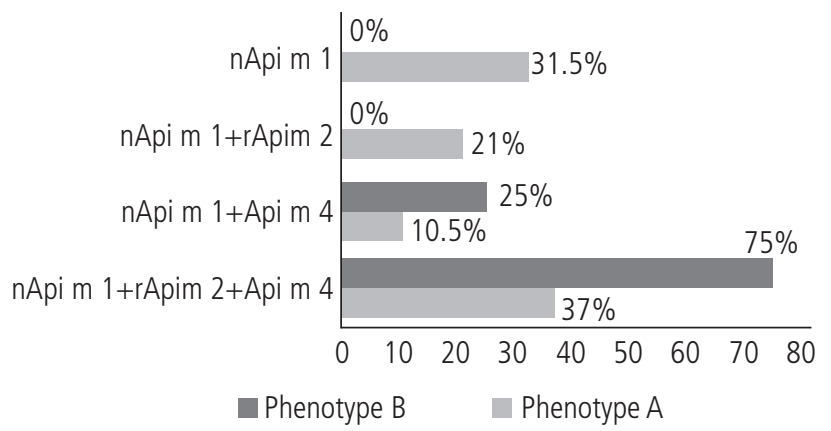

Figure 2. Sensitization profile (\%) for phenotype A (slgE to Api $m 4$ $<0.98 \mathrm{kU} / \mathrm{L}$ ) and phenotype $\mathrm{B}$ (slgE to Api $\mathrm{m} 4 \geq 0.98 \mathrm{kU} / \mathrm{L}$ ). nApi indicates native Api; slgE, specific lgE.

\section{Immune Changes}

Table 2 shows the changes in sIgE and sIgG4 levels and ID responses at the end of years 1 and 2 compared with baseline.

\section{Results for Phenotype $B$}

\section{Clinical Changes}

\section{bVIT Safety}

All 12 patients in group B were treated with NA. Four and 8 patients were administered a maintenance dose of $100 \mu \mathrm{g}$ and $200 \mu \mathrm{g}$, respectively. At the start of bVIT, 2 patients had a Müller grade I reaction and 1 had a Müller grade III reaction. Two patients had 17 SRs, and 15 of these occurred despite premedication ( 6 grade I reactions and 11 grade III reactions). One patient continued to experience SRs during maintenance therapy. One patient withdrew after completing the build-up phase due to reasons unrelated to the study.

\section{Sting Challenge}

One patient in group B did not undergo the sting challenge test due to constant SRs during maintenance, and was counted as a treatment failure (intention to treat). Another patient had grade III SRs in both the first and second years of therapy. The efficacy of bVIT in this group thus was $82 \%$.

\section{Immune Changes}

Table 2 shows the changes in immune marker levels (sIgE, sIgG4, ID) for group B.

\section{Discussion}

We introduced a component-resolved-diagnosis (CRD) tool into our daily clinical practise to search for phenotype differences that would enable better management of HBVallergic patients, with a focus on immunotherapy safety and efficacy biomarkers. 
Table 2. Immune Changes by Phenotype A and B

\begin{tabular}{|c|c|c|c|c|c|c|c|c|c|c|}
\hline & \multicolumn{5}{|c|}{ Phenotype $A^{a}(n=18)$} & \multicolumn{5}{|c|}{ Phenotype $B^{a}(n=11)$} \\
\hline & Baseline & Year 1 & $\begin{array}{c}P \\
\text { Value }^{\mathrm{b}}\end{array}$ & Year 2 & $\begin{array}{c}P \\
\text { Value }^{\mathrm{c}}\end{array}$ & Baseline & Year 1 & $\begin{array}{c}P \\
\text { Value }^{\mathrm{b}}\end{array}$ & Year 2 & $\begin{array}{c}P \\
\text { Value }^{\mathrm{c}}\end{array}$ \\
\hline $\begin{array}{l}\text { sIgE Apis, median } \\
\text { (IQR), kU/L }\end{array}$ & $\begin{array}{c}4 \\
(11.5)\end{array}$ & $\begin{array}{c}2 \\
(5.6)\end{array}$ & .038 & $\begin{array}{c}2 \\
(4.8)\end{array}$ & .02 & $\begin{array}{c}42 \\
(63.5)\end{array}$ & $\begin{array}{c}15 \\
(31)\end{array}$ & .001 & $\begin{array}{c}13.4 \\
(14.2)\end{array}$ & .001 \\
\hline ID improvement, ${ }^{\mathrm{d}}$ No. & - $\quad-$ & 9 & .02 & 9 & NS & - & 4 & NS & 4 & NS \\
\hline $\begin{array}{l}\text { sIgE nApi m 1, } \\
\text { median (IQR), kU/L }\end{array}$ & $\begin{array}{c}5.2 \\
(11.9)\end{array}$ & $\begin{array}{c}3 \\
(6.2)\end{array}$ & .02 & $\begin{array}{c}2.3 \\
(5.3)\end{array}$ & .01 & $\begin{array}{c}63.3 \\
(92.8)\end{array}$ & $\begin{array}{c}20.6 \\
(32.5)\end{array}$ & .013 & $\begin{array}{c}23 \\
(39.7)\end{array}$ & .002 \\
\hline $\begin{array}{l}\text { sIgErApi m 2, } \\
\text { median (IQR), kU/L }\end{array}$ & $\begin{array}{l}1.55 \\
(6.9)\end{array}$ & $\begin{array}{c}5.3 \\
(10.3)\end{array}$ & NS & $\begin{array}{c}3.9 \\
(10.5)\end{array}$ & NS & $\begin{array}{c}9 \\
(162.6)\end{array}$ & $\begin{array}{c}3.5 \\
(44)\end{array}$ & NS & $\begin{array}{l}4.33 \\
(33)\end{array}$ & NS \\
\hline $\begin{array}{l}\text { sIgE Api m 4, } \\
\text { median (IQR), kU/L }\end{array}$ & $\begin{array}{l}0.33 \\
(0.5)\end{array}$ & $\begin{array}{l}0.29 \\
(0.4)\end{array}$ & NS & $\begin{array}{l}0.25 \\
(0.3)\end{array}$ & NS & $\begin{array}{c}3.7 \\
(8.7)\end{array}$ & $\begin{array}{c}1.2 \\
(3.1)\end{array}$ & .004 & $\begin{array}{l}0.7 \\
(1.4)\end{array}$ & .002 \\
\hline $\begin{array}{l}\text { sIgG4 Apis, } \\
\text { median (IQR), } \mu \mathrm{g} / \mathrm{mL}\end{array}$ & $\begin{array}{c}688 \\
(1519)\end{array}$ & $\begin{array}{c}5130 \\
(6210)\end{array}$ & .001 & $\begin{array}{c}4378 \\
(5721)\end{array}$ & .001 & $\begin{array}{c}2213 \\
(6582)\end{array}$ & $\begin{array}{l}10522 \\
(9734)\end{array}$ & .001 & $\begin{array}{c}12436 \\
(15049)\end{array}$ & .002 \\
\hline $\begin{array}{l}\text { sIgG4 Api m 1, } \\
\text { median (IQR), } \mu \mathrm{g} / \mathrm{mL}\end{array}$ & $\begin{array}{c}1.3 \\
(2.4)\end{array}$ & $\begin{array}{l}4.1 \\
(6)\end{array}$ & .0001 & $\begin{array}{l}5.4 \\
(6)\end{array}$ & .0001 & $\begin{array}{c}3.1 \\
(3.4)\end{array}$ & $\begin{array}{l}8.5 \\
(7)\end{array}$ & .001 & $\begin{array}{c}7.7 \\
(6.7)\end{array}$ & .001 \\
\hline
\end{tabular}

Abbreviations: Apis, Apis mellifera; ID, intradermal test; nApi m 1; native Api m 1;NS, nonsignificant; slgE, specific lgE; slgG4, specific lgG4.

aGroup A: slgE to Api m $4<0.98 \mathrm{kU} / \mathrm{L}$; Group B: slgE to Api m $4 \geq 0.98 \mathrm{kU} / \mathrm{L}$.

${ }^{\mathrm{b}} P$ value resulting from the comparison of data at the end of the first year with baseline values.

$c P$ value resulting from the comparison of data at the end of the second year with baseline values.

dID improvement was defined as a reduction in the concentration eliciting a positive response.

Api $\mathrm{m} 1$ is the dominant sensitizer in patients with HBV allergy, regardless of whether the native [6] or recombinant $[4,5]$ antigen is used. In the present study, nApi $\mathrm{m} 1$ was recognized by $100 \%$ of patients, who were divided into 2 phenotype groups on the basis of a cutoff of $0.35 \mathrm{kU} / \mathrm{L}$. The prevalence of sensitization to rApi $\mathrm{m} 2$ in our population (52.6\% in group A and $75 \%$ in group B) is higher than the rates of $47.9 \%$ and $52.2 \%$ described respectively by Köhler et al [4] and Sturm et al [9]. This may be due to regional differences or to the presence of sensitizing sources other than $\mathrm{HBV}$, as Api $\mathrm{m} 2$ has been recognized as a cross-reactivity marker between bee and wasp venoms [16]. The third allergen studied, the synthetic peptide Api m 4, was detected in $47 \%$ of patients in group A; this rate is similar to that described in a recent study [9]. Api $\mathrm{m} 4$ can be considered a major allergen in our population as it was recognized by $100 \%$ of patients in group A, again confirming the findings of a previous study [10]. Overall, these data suggest that phenotype A patients have a similar sensitization profile to that previously described, while phenotype B patients have a high rate of polysensitization.

All the patients in our series who were sensitized to Api m 4 were also sensitized to nApi $m 1(0.35 \mathrm{kU} / \mathrm{L})$ and some were also sensitized to rApi $\mathrm{m} 2$, leading us to think that sIgE-Api $m 4$ could be a marker of advanced allergic march, hence representing a more complex form of the disease with a different sensitization pattern.

Using sIgE-Api m 4 as the only discrimination criterion (and one based on an arbitrary cutoff in the absence of knowledge about the true potential of Api m 4 to generate an $\mathrm{IgE}$ response when the protocol was decided), we found that patients in group B (IgE $\geq 0.98 \mathrm{kU} / \mathrm{L})$ experienced more serious SRs after bee stings and also had higher baseline skin sensitivity and sIgE levels to full Apis venom and nApi $m 1$.
They also had higher baseline sIgG4-Apis levels, suggesting a higher number of prior stings, as described by Müller [17], although the proportion of beekeepers and the age of the patients were similar in both groups. The above findings all suggest that phenotype B might be a more complex or even possibly a more advanced form of the disease.

We observed a high incidence of SRs to bVIT in some phenotype B patients. This could be due to individual predisposition factors (higher levels of sIgE-Apis, sIgEnApi $m$, and sIgE-Api $m$ 4), thereby supporting the value of Api $\mathrm{m} 4$ as a marker of poor tolerance to bVIT, or to factors in the NA extract [18]. Tryptase levels, however, were normal and the build-up phase we used was proven to be safe in a previous study that used the same extract [14]. Furthermore, neither of these factors was found to be associated with poor VIT tolerance in a multicenter trial [19].

Known bVIT-induced immune changes [20,21], measured by a reduction in sIgE-Apis percentages and an increase in sIgG4-Apis percentages, were confirmed in both phenotype groups in our series. A similar pattern was observed for sIgEnApi $\mathrm{m} 1$ and sIgG4-Api m 1, supporting previous findings for sIgE-nApi m 1 [22] and sIgG4-Api m 1 [4].

sIgE-Api $\mathrm{m} 4$ levels decreased significantly in group B but not in group A after the first year of bVIT. This absence of reduction in phenotype A patients is logical considering that they had minimum levels at the beginning of treatment and that the Apim 4 component is depleted in the PA extract. It would have been interesting to determine IgG4-Api m4 levels to confirm response to immunotherapy at this stage. Köhler et al [4] demonstrated this response in a group of 20 patients, although they did not specify the extract used [4]. The approach we propose can indirectly address the general lack of knowledge about allergen content in standardized hymenoptera venom vaccines. 
Skin sensitivity in phenotype B patients was high at baseline and did not decrease significantly after 1 year of immunotherapy, coinciding with previous findings [23]. In addition, it has been reported that changes only become obvious after 5 years of therapy [21,22]. Patients in group A showed a reduction in skin reactivity after the first year of bVIT, suggesting a difference involving the inflammatory parameters of skin mast cells, which may be altered by immunotherapy in addition to changes in serum immunoglobulin.

In some cases, spontaneous field stings can provide information that confirms clinical protection during or after bVIT. However, spontaneous stings are always unpredictable, as low quantities of venom may be injected and the response is never verified.

In our study, patients underwent a controlled sting challenge test 1 and 2 years after starting continuous bVIT to confirm protection. We performed 2 sting challenges, as it has been shown for patients allergic to yellow jacket venom that a single tolerated re-sting challenge does not ensure maximum protection [24]. In our study, $100 \%$ of phenotype A patients achieved protection in the first year and this was sustained in the second year. Ruëff et al [20] reported a failure rate of $15 \%$ for bVIT with the same purified extract. The authors attributed this failure to insufficient dosage in the corresponding subgroup of patients, who had an unknown phenotype. Eighty-two percent of phenotype B patients achieved protection after the first year of bVIT, and this rate did not improve during the second year. Of the 2 patients who did not achieve protection, one was not subject to a re-sting (the patient had experienced spontaneous stings with milder systemic reactions than before initiation of bVIT), and the other one developed early cervico-facial erythema and wheezing after 2 in-hospital re-stings that responded well to adrenaline. The dose was increased to $200 \mu \mathrm{g} / 4 \mathrm{wk}$ after the first positive sting test, and to $300 \mu \mathrm{g} / 4 \mathrm{wk}$ after the second one. Both patients experienced repeated SRs during initiation of bVIT, and the first patient also experienced SRs during maintenance therapy, confirming that poor tolerance of bVIT is a predictor of treatment failure [2].

The fact that bVIT achieved an overall protection rate of $93 \%$ in our population, which is even higher than that reported for other series $[2,25]$, suggests that a strategy similar to that proposed in this study could be appropriate for ensuring adequate selection of extracts. A review in 2010 indicated that the efficacy of purified and nonpurified (native) bee venom extracts is similar, although unlike in our case, possible patient variability was not taken into account [26].

Despite the possible limitations related to sample size and number of available allergens, the findings of this pilot study show that people have different forms of HBV allergy. During clinical practice we identified a subpopulation of patients with sting-induced anaphylactic reactions including respiratory or hemodynamic instability who showed high skin sensitivity, sIgE-Api m4 levels of over $0.98 \mathrm{kU} / \mathrm{L}$, and were predisposed to SRs during bVIT. We called this group phenotype $B$ and administered the patients a full HBV extract, which was successful in $82 \%$ of cases. During follow-up we confirmed a lack of significant improvement in ID results but a considerable reduction in sIgE-nApi $m 1$ and sIgEApi $\mathrm{m} 4$ levels. The response to rApi $\mathrm{m} 2$ was not significant. Phenotype $\mathrm{B}$ includes patients who might benefit from specific interventions from early on, such as premedication during bVIT (which has already been proposed as a means of achieving better tolerance [27-29]), different build-up phases, or use of higher venom doses [30].

The results of the current study highlight the need to conduct well-designed multicenter studies including large populations and to explore the possibilities offered by component-resolved diagnosis and therapeutic options based on sensitization profiles. These profiles could then be used as markers for disease severity and treatment response, thus increasing the potential benefits of therapy and improving the risk-benefit balance for patients with this life-threatening disease.

\section{Acknowledgments}

The authors express their gratitude to Fernando de la Torre, Lucía Jimeno, and Agustín Galan (ALK-Abello S.A.) for their technical support.

\section{Funding}

The authors declare that no funding was received for the present study.

\section{Conflicts of Interest}

The authors declare that they have no conflicts of interest. The Research Department at ALK-Abelló S.A supported the study by performing IgE determinations.

\section{References}

1. Boyle RJ, Elremeli M, Hockenhull J, Cherry MG, Bulsara MK, Daniels M, Oude Elberink J. Venom immunotherapy for preventing allergic reactions to insect stings. Cochrane database Syst Rev. 2012;10:CD008838.

2. Ruëff F, Vos B, Oude Elberink J, Bender $A$, Chatelain R, DugasBreit S, Horny H-P, Kuchenhoff H, Linhardt A, Mastnik S, Sotlar K, Stretz E, Vollrath R, Przybilla B, Flaig M. Predictors of clinical effectiveness of Hymenoptera venom immunotherapy. Clin Exp Allergy. 2014;44:736-46.

3. Allergen nomenclature. WHO/IUIS Allergen Nomenclature Subcommittee. [Internet]. Available from: http://www.allergen. org/search.php?allergenname=\&allergensource=Apis+mellifer a\&TaxSource=\&TaxOrder=\&foodallerg=all\&bioname=

4. Köhler J, Blank S, Müller S, Bantleon F, Frick M, Huss-Marp J, Lidholm J, Spillner E, Jakob T. Component resolution reveals additional major allergens in patients with honeybee venom allergy. J Allergy Clin Immunol. 2014;133:1383-9.

5. Muller UR, Johansen N, Petersen AB, Fromberg-Nielsen J, Haeberli G. Hymenoptera venom allergy: analysis of double positivity to honey bee and Vespula venom by estimation of $\mathrm{lgE}$ antibodies to species-specific major allergens Api $\mathrm{m} 1$ and Ves v5. Allergy. 2009;64:543-8.

6. Korošec P, Valenta R, Mittermann I, Celesnik N, Eržen R, Zidarn M, Kosnik M. Low sensitivity of commercially available rApi m 1 for diagnosis of honeybee venom allergy. J Allergy Clin Immunol. 2011;128:671-3.

7. Soldatova LN, Crameri R, Gmachl M, Kemeny DM, Schmidt M, Weber M, Mueller UR. Superior biologic activity of the 
recombinant bee venom allergen hyaluronidase expressed in baculovirus-infected insect cells as compared with Escherichia coli. J Allergy Clin Immunol. 1998;101:691-8.

8. King TP, Spangfort MD. Structure and biology of stinging insect venom allergens. Int Arch Allergy Immunol. 2000;123:99-106.

9. Sturm GJ, Hemmer W, Hawranek T, Lang R, Ollert M, Spillner E, Blank S, Bokanovic D, Aberer W. Detection of lgE to recombinant Api $m 1$ and $r$ Ves $v 5$ is valuable but not sufficient to distinguish bee from wasp venom allergy. J Allergy Clin Immunol. 2011;128:247-8.

10. Ruiz B, Serrano P, Verdú M, Moreno C. Sensitization to Api m 1, Api m 2, and Api $m$ 4: association with safety of bee venom immunotherapy. Ann Allergy Asthma Immunol. 2015;114:350-2.

11. Mueller HL. Diagnosis and treatment of insect sensitivity. J Asthma Res. 1966;3:331-3.

12. Petersen $A B$, Gudmann $P$, Milvang-Grønager $P$, Mørkeberg $R$, Bøgestrand S, Linneberg A, Johansen N. Performance evaluation of a specific IgE assay developed for the ADVIA centaur immunoassay system. Clin Biochem. 2004;37:882-92.

13. Bonifazi F, Jutel M, Biló BM, Birnbaum J, Muller U. Prevention and treatment of hymenoptera venom allergy: guidelines for clinical practice. Allergy. 2005;60:1459-70.

14. Sanchez-Machin I, Moreno C, Gonzalez R, Iglesias-Souto J, Perez $E$, Matheu V. Safety of a 2-visit cluster schedule of venom immunotherapy in outpatients at risk of life-threatening anaphylaxis. J Investig Allergol Clin Immunol. 2010;20:91-2.

15. Moreno C, Barasona MJ, Serrano P, Justicia JL, Ruz JM, Guerra F. Alternating Polistes-Vespula venom immunotherapy: a therapeutic strategy to resolve a diagnostic deficiency. J Investig Allergol Clin Immunol. 2011;21:28-33.

16. Mittermann I, Zidarn M, Silar M, Markovic-Housley Z, Aberer W, Korošec P, Kosnik M, Valenta R. Recombinant allergenbased IgE testing to distinguish bee and wasp allergy. J Allergy Clin Immunol. 2010;125:1300-7 e3.

17. Müller U, Johansson SG, Streit C. Hymenoptera sting hypersensitivy: $\lg \mathrm{E}, \lg \mathrm{G}$ and haemagglutinating antibodies to bee venom constituents in relation to exposure and clinical reaction to bee stings. Clin Allergy. 1978;8:267-72.

18. Bilo MB, Cinti B, Brianzoni MF, Braschi MC, Bonifazi M, Antonicelli L. Honeybee venom immunotherapy: a comparative study using purified and nonpurified aqueous extracts in patients with normal Basal serum tryptase concentrations. J Allergy. 2012;869243.

19. Rueff $F$, Przybilla B, Bilo MB, Müller U, Scheipl F, Aberer W, Birnbaum J, Bodzenta-Lukaszyk A, Bonifazi F, Bucher C, Campi P, Darsow U, Egger C, Haeberli G, Hawranek T, Kucharewicz I, Kuchenhoff H, Lang R, Quercia O, Reider N, Severino M, Sticherling M, Sturm GJ, Wuthrich B. Predictors of side effects during the buildup phase of venom immunotherapy for Hymenoptera venom allergy: the importance of baseline serum tryptase. J Allergy Clin Immunol. 2010;126:105-11 e5.

20. Rueff F, Wolf $H$, Schnitker J, Ring J, Przybilla B. Specific immunotherapy in honeybee venom allergy: a comparative study using aqueous and aluminium hydroxide adsorbed preparations. Allergy. 2004;59:589-95.

21. Quercia O, Emiliani F, Pecora S, Burastero SE, Stefanini GF. Efficacy, safety, and modulation of immunologic markers by immunotherapy with honeybee venom: comparison of standardized quality depot versus aqueous extract. Allergy Asthma Proc. 2006;27:151-8.

22. Carballada $F$, Boquete $M$, Nunez $R$, Lombardero $M$, de la Torre F. Follow-up of venom immunotherapy (VIT) based on conventional techniques and monitoring of immunoglobulin $\mathrm{E}$ to individual venom allergens. J Investig Allergol Clin Immunol. 2010;20:506-13.

23. Pasaoglu G, Sin BA, Misirligil Z. Rush hymenoptera venom immunotherapy is efficacious and safe. J Investig Allergol Clin Immunol. 2006;16:232-8.

24. Franken $H H$, Dubois $A E$, Minkema $H J$, van der Heide $S$, de Monchy JG. Lack of reproducibility of a single negative sting challenge response in the assessment of anaphylactic risk in patients with suspected yellow jacket hypersensitivity. J Allergy Clin Immunol. 1994;93:431-6.

25. Ruëff $F$, Przybilla B, Biló MB, Müller U, Scheipl F, Seitz MJ, Aberer W, Bodzenta-Lukaszyk A, Bonifazi F, Campi P, Darsow U, Haeberli G, Hawranek T, Kuchenhoff $H$, Lang R, Quercia 0 , Reider $N$, Schmid-Grendelmeier $P$, Maurizio Severino M, Sturm GJ, Treudler R, Wuthrich B. Clinical effectiveness of hymenoptera venom immunotherapy: a prospective observational multicenter study of the European academy of allergology and clinical immunology interest group on insect venom hypersensitivity. PLoS One. 2013;8:e63233.

26. Bilo MB, Antonicelli L, Bonifazi F. Purified vs. nonpurified venom immunotherapy. Curr Opin Allergy Clin Immunol. 2010;10:330-6.

27. Müller U, HariY, Berchtold E. Premedication with antihistamines may enhance efficacy of specific-allergen immunotherapy. J Allergy Clin Immunol. 2001;107:81-6.

28. Müller UR, Jutel $M$, Reimers $A$, Zumkehr J, Huber $C$, Kriegel C, Steiner U, Haeberli G, Akdis M, Helbling A, Schnyder B, Blaser K, Akdis C. Clinical and immunologic effects of $\mathrm{H} 1$ antihistamine preventive medication during honeybee venom immunotherapy. J Allergy Clin Immunol. 2008;122:1001-7 e4.

29. Reimers A, Hari Y, Muller U. Reduction of side-effects from ultrarush immunotherapy with honeybee venom by pretreatment with fexofenadine: a double-blind, placebocontrolled trial. Allergy. 2000;55:484-8.

30. Ruëff $F$, Wenderoth A, Przybilla B. Patients still reacting to a sting challenge while receiving conventional Hymenoptera venom immunotherapy are protected by increased venom doses. J Allergy Clin Immunol. 2001;108:1027-32.

\section{Manuscript received September 5, 2015; accepted for publication, January 2016.}

\section{Berta Ruiz León}

\author{
Department of Allergology \\ Reina Sofia University Hospital. \\ Avda Menendez Pidal s/n \\ 14004 Córdoba, Spain \\ E-mail: mb.ruiz.sspa@juntadeandalucia.es
}

